SECTION 4. Computer science, computer engineering and automation.

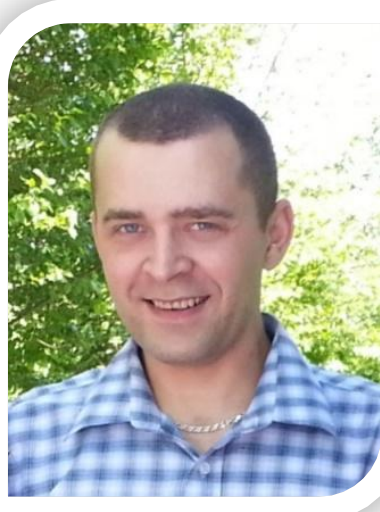

\author{
Shevtsov Alexandr Nikolayevich \\ candidate of technical Sciences, \\ President, Theoretical \& Applied Science, LLP, \\ associate Professor of the Department «Applied \\ mathematics» \\ Taraz State University named after M.Kh. Dulati, \\ Kazakhstan
}

\title{
ABOUT SOME ALGORITHMS, AUTOMATED DOCUMENT MANAGEMENT PROGRAMS
}

In the article there are considered some issues of programming on Delphi workflow automation.

Keyword: documents, automation.

Currently there are different workflow systems:ELMA, СЭД, Docsvision, 1C, Е1 Евфрат, Directum, ИНТАЛЕВ, Escom, Optima-WorkFlow, Гран-Док, Летограф, Documetr and many others [1-10].

Selecting one of these systems is rather complicated, because each of them is a document repository, and can be rated by different parameters [7, C.1]:

- card documents;

- security;

- storage and tracking multiple versions of documents;

- search function;

- automatic notification;

- routes of passage of documents and setting the tasks to people;

- user-friendly interface;

- scanning and recognition of documents processed.

An important aspect of the selection can be and the price system: 
Table 1.

The cost of the systems of electronic document circulation

\begin{tabular}{|c|c|}
\hline System name & The price in rubles, including VAT \\
\hline Directum & $\begin{array}{l}22,800 \text { rubles for installation of the module on the server } \\
\text { and } 165,300 \text { rubles - automation } 20 \text { jobs. } \\
\text { Note: for more system functions are implemented in } \\
\text { separate modules, you have to pay separately. }\end{array}$ \\
\hline Escom.doc & $\begin{array}{l}80,000 \text { roubles. } \\
\text { Note: The delivery includes a license to use the program } \\
\text { on the server and up to } 20 \text { simultaneous connections. }\end{array}$ \\
\hline Optima-WorkFlow & $\begin{array}{l}\text { just } 260,000 \text { rubles for the basic version, which will run for } \\
10 \text { users } \\
\text { Note: } 60,000 \text { rubles'll have to pay for automation of } 10 \\
\text { additional jobs. As is the case with the previous system, } \\
\text { some modules have to purchase separately, as they are not } \\
\text { included in the basic set. }\end{array}$ \\
\hline PayDox & $\begin{array}{l}90,000 \text { rubles per basic version } \\
\text { There is a reference document types, where you set up the } \\
\text { possible types of cards. } \\
\text { There are reserved fields that you can use at its discretion, } \\
\text { and you can also add your own fields directly in the } \\
\text { database, or use additional data sources, including direct } \\
\text { access to other information systems. }\end{array}$ \\
\hline «Гран-Док» & $\begin{array}{l}30,000 \text { rubles for the basic version for } 5 \text { users. } \\
\text { Note: } 675,00 \text { rubles Supplement for automation additional } \\
15 \text { jobs. }\end{array}$ \\
\hline $\begin{array}{l}\text { «ИНТАЛЕВ: } \\
\text { Корпоративные } \\
\text { документы } \\
\text { процессы» }\end{array}$ & $\begin{array}{l}45,000 \text { rubles per basic version for } 5 \text { users. } \\
\text { Note: } 4,000 \text { rubles will cost every additional workplace. }\end{array}$ \\
\hline $\begin{array}{l}\text { «ЕВФРАТ- } \\
\text { Документооборот» }\end{array}$ & $\begin{array}{l}110,000 \text { rubles } \\
\text { Note: the complex on } 20 \text { users include license }\end{array}$ \\
\hline
\end{tabular}




\begin{tabular}{|l|l|}
\hline & $\begin{array}{l}\text { «EUPHRATES-document circulation Customer and } \\
\text { EUPHRATES-document circulation Server». }\end{array}$ \\
\hline «Летограф» & $\begin{array}{l}\text { The cost of one license is 10995 rubles. } \\
\text { Note: the License gives the right to use all the features of } \\
\text { the platform. The license fee includes the cost of the } \\
\text { license on the database that is installed on the server. }\end{array}$ \\
\hline
\end{tabular}

The average price of the system is 100 thousand rubles, or about $\$ 3$ thousand, and the cheapest development - about 300-400 dollars.

Table 2.

The results of the testing of the systems of electronic document circulation

\begin{tabular}{|c|c|c|c|c|c|c|c|c|}
\hline The functionality of the system & 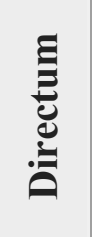 & 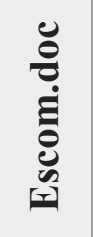 & 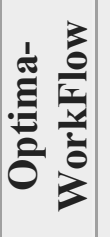 & 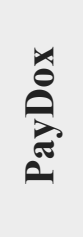 & 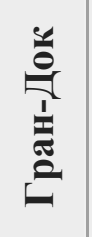 & 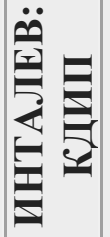 & $\begin{array}{l}5 \\
\bar{\theta} \\
0\end{array}$ & 竞 \\
\hline Possibility of card document & 5 & 5 & 5 & 4 & 4 & 4 & 4 & 5 \\
\hline Security & 4 & 5 & 5 & 4 & 5 & 5 & 4 & 5 \\
\hline The ability to store versions & 5 & 4 & 5 & 5 & 4 & 5 & нет & 3 \\
\hline Searchable repository of documents & 5 & 5 & 5 & 4 & 5 & 5 & 5 & 5 \\
\hline $\begin{array}{l}\text { The possibility of notification during } \\
\text { document processing }\end{array}$ & 3 & 4 & 5 & 4 & 4 & 5 & 3 & 3 \\
\hline $\begin{array}{l}\text { Routing capabilities and forming tasks } \\
\text { users }\end{array}$ & 5 & 4 & 5 & 4 & 1 & 4 & 3 & 4 \\
\hline Possibility of integration with e-mail & 5 & 3 & 4 & 4 & 4 & 4 & 5 & 5 \\
\hline Archiving obsolete documents & 4 & 3 & 4 & 4 & 1 & 3 & 4 & 2 \\
\hline $\begin{array}{l}\text { The possibility of creating a distributed } \\
\text { storage structure }\end{array}$ & 5 & нет & 4 & 2 & 3 & 4 & 4 & 4 \\
\hline The convenience of the interface & 5 & 3 & 5 & 3 & 5 & 5 & 5 & 3 \\
\hline $\begin{array}{l}\text { The possibility of scanning and } \\
\text { recognition of documents }\end{array}$ & 5 & 3 & 3 & 2 & 3 & 3 & 5 & 3 \\
\hline GPA & 4,6 & 3,5 & 4,5 & 3,6 & 3,5 & 4,2 & 3,8 & 3,7 \\
\hline
\end{tabular}

One point - functionality is present in the minimum amount, 5 points - the function is implemented to the fullest. 
Moreover, the continuous updating of the cards of documents, and certain types of documents the programs may not have absolutely.

Card - is a file with the settings, determining the source form, built-in labels, as well as changing information and data to be filled in each document individually.

Consider the process of creation of an automated document management system on the example of filling out the forms in the mail.

We need the original form:

Set the two existing size forms of $\mathrm{C} 4$ and $\mathrm{C} 5,20 \times 30$ and $16 \times 23$ respectively.

code: Delphi

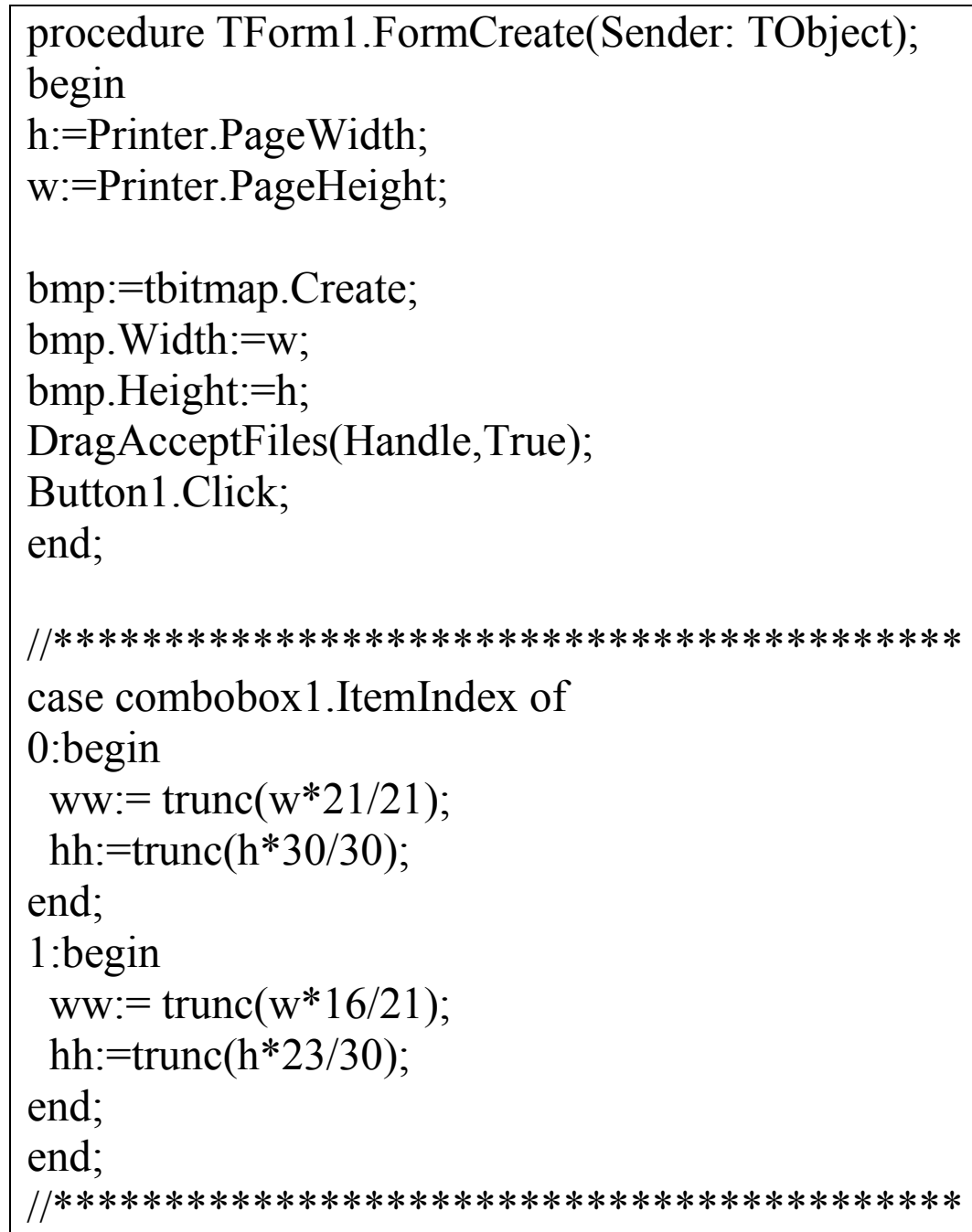

Fill in the blank background information (details), as well as the necessary lines and signs.

code: Delphi

procedure TForm1.Button1Click(Sender: TObject); 


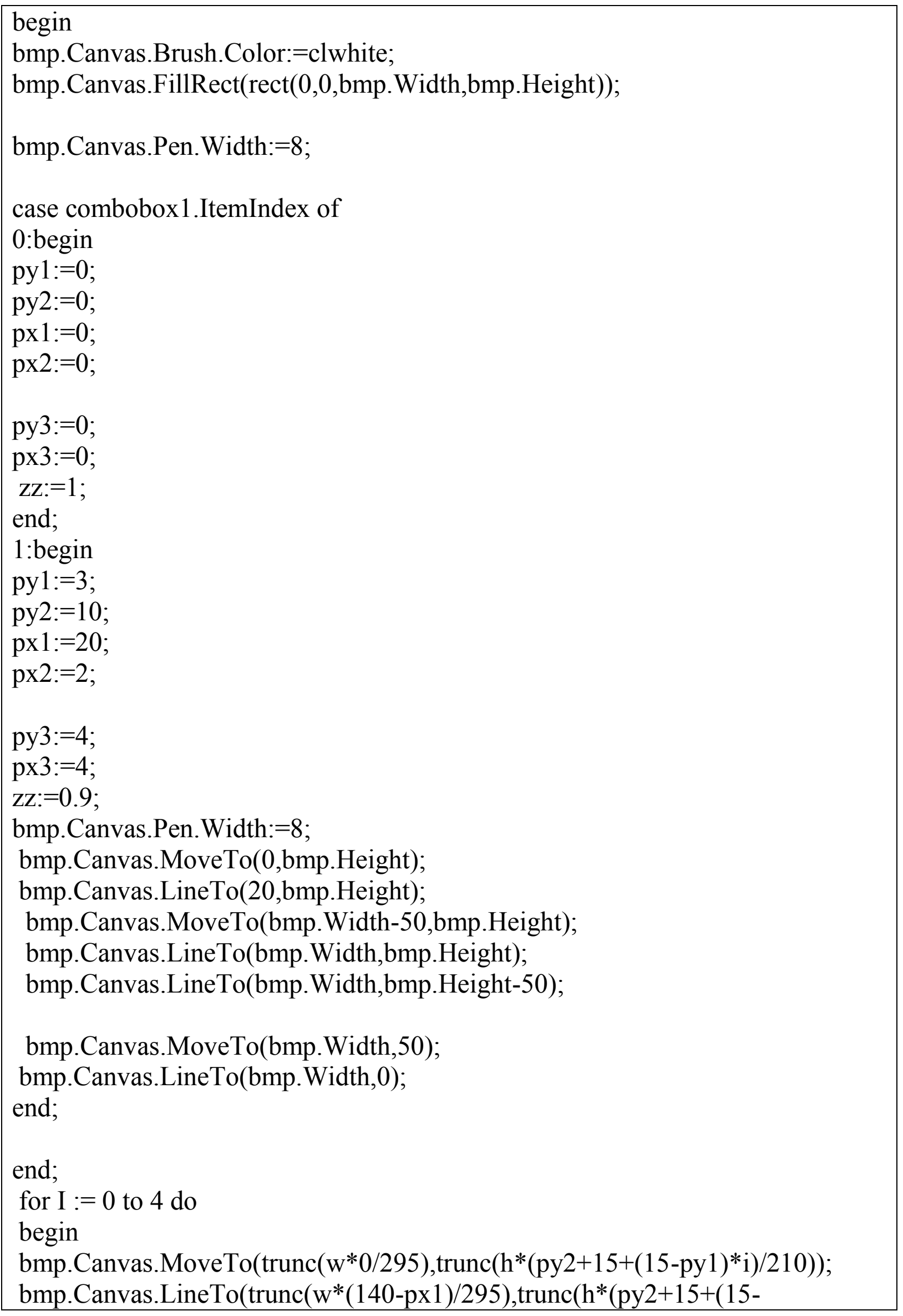




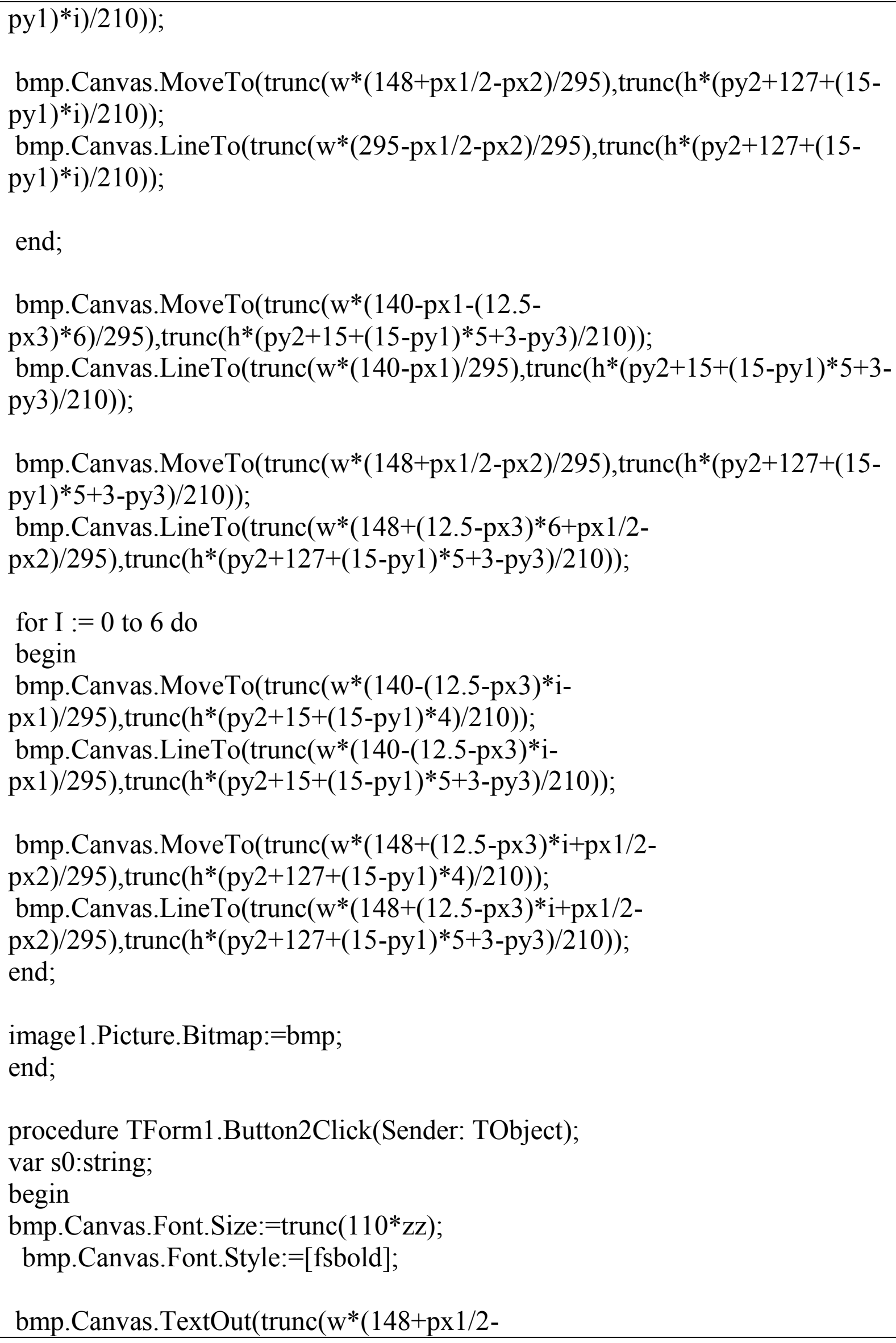


px2+25)/295), trunc(h*(py2+127+(15-py1)*3-9)/210),s2+' '+Edit1.Text); bmp.Canvas.TextOut(trunc $\left(\mathrm{w}^{*}(148+\mathrm{p} \times 1 / 2-\right.$ px2+25)/295), trunc(h*(py2+127+(15-py1)*4-9)/210),s1+' '+Edit2.Text); image1.Picture.Bitmap:=bmp; end;

Data about the client will receive from an external source (the questionnaire of the client, Microsoft Exel), highlight, and automatically put them on the card.

code: Delphi

procedure TForm1.WMDropFiles(var Msg: TMessage);

Var

Filename: $\operatorname{array}[0 . .256]$ of char;

begin

DragQueryFile(THandle(Msg.WParam),0,Filename,SizeOf(Filename));

label1.caption:=FileName;

label2.caption:=extractfilename(label1.caption);

BitBtn1.Click;

DragFinish(THandle(Msg.WParam)); end;

Open access to the server Exel, for direct work with the document, getting data from certain cells and load it into the card.

code: Delphi

procedure TForm1.BitBtn1Click(Sender: TObject);

begin

button1.Click;

$/ /$ begin

if $\mathrm{p}=1$ then ExcelApp.Workbooks.Close; $\mathrm{p}:=1$;

// а потом и ворд

//ExcelApp.Quit;

$/ /$ end;

try // Create a Word Instance

ExcelApp := CreateOleObject('Excel.Application');

except

// Error... 


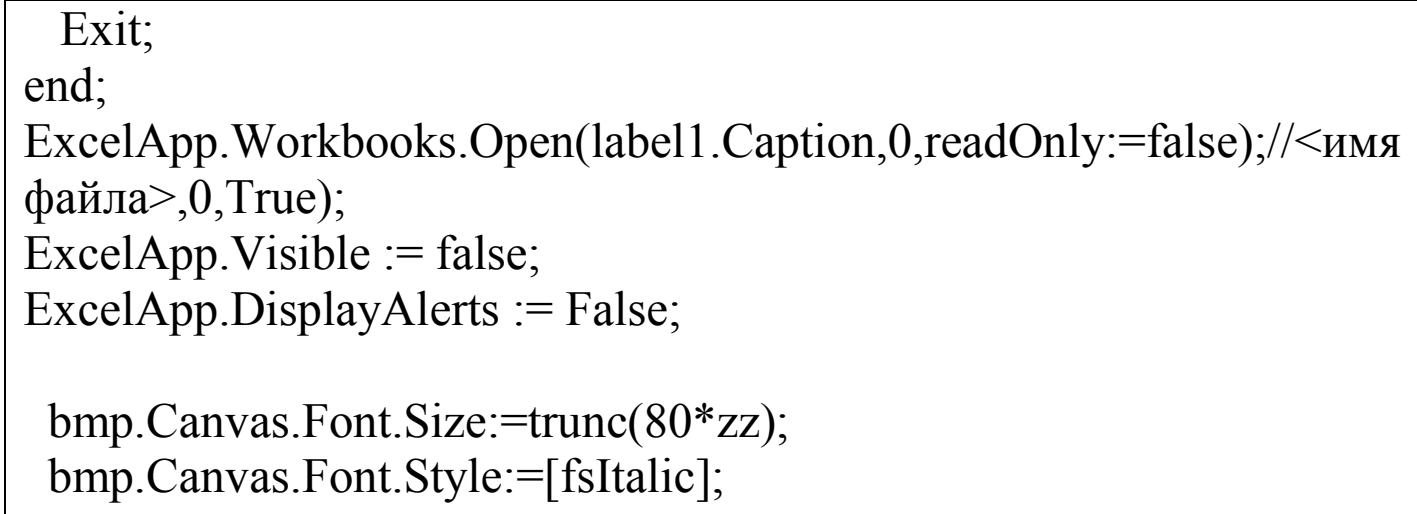

bmp.Canvas.TextOut(trunc $\left(\mathrm{w}^{*} 0 / 295\right), \operatorname{trunc}(\mathrm{h} *(\mathrm{py} 2+15+(15-\mathrm{py} 1) * 0-$

4)/210),'От кого ');

bmp.Canvas.TextOut(trunc(w*0/295), trunc $(\mathrm{h} *(\mathrm{py} 2+15+(15-\mathrm{py} 1) * 2-$

4)/210),'Откуда ');

bmp.Canvas.Font.Size: $=\operatorname{trunc}(60 * z z)$;

bmp.Canvas. TextOut(trunc(w*(140-px1-(12.5-

px3)*6)/295), trunc(h*(py2+15+(15-py1)*4-5)/210),'Индекс ');

bmp.Canvas.Font.Size: $=\operatorname{trunc}(80 * \mathrm{zz})$;

bmp.Canvas. TextOut(trunc(w*(148+px1/2-px2)/295), trunc(h*(py2+127+(15py1)*0-4)/210),'Кому ');

bmp.Canvas. TextOut(trunc( $\mathrm{w} *(148+\mathrm{px} 1 / 2-\mathrm{px} 2) / 295)$, trunc(h*(py2+127+(15py1)*2-4)/210),'Куда ');

bmp.Canvas.Font.Size: $=\operatorname{trunc}(60 * \mathrm{zz})$;

bmp.Canvas. TextOut $(\operatorname{trunc}(\mathrm{w} *(148+\mathrm{px} 1 / 2-\mathrm{px} 2) / 295)$, trunc(h*(py2+127+(15py1)*4-5)/210),'Индекс ');

bmp.Canvas.Font.Size:=trunc $\left(110^{*} \mathrm{zz}\right)$;

bmp.Canvas.Font.Style:=[fsbold];

bmp.Canvas. TextOut(trunc(w*25/295), trunc $(\mathrm{h} *(\mathrm{py} 2+15+(15-\mathrm{py} 1) * 0-$

9)/210),'Шевцов А.Н.');

bmp.Canvas.TextOut(trunc(w*25/295), trunc(h*(py2+15+(15-py1)*2-

9)/210),'ул.Джамбулская 128');

bmp.Canvas.TextOut(trunc(w*25/295), trunc $(\mathrm{h} *(\mathrm{py} 2+15+(15-\mathrm{py} 1) * 3-$

9)/210),'г.Тараз, Жамбылская обл.');

bmp.Canvas.TextOut(trunc(w*25/295), $\operatorname{trunc}(\mathrm{h} *(\mathrm{py} 2+15+(15-\mathrm{py} 1) * 4-9) / 210),{ }^{\prime}$ Казахстан');

bmp.Canvas.Font.Style:=[]; 


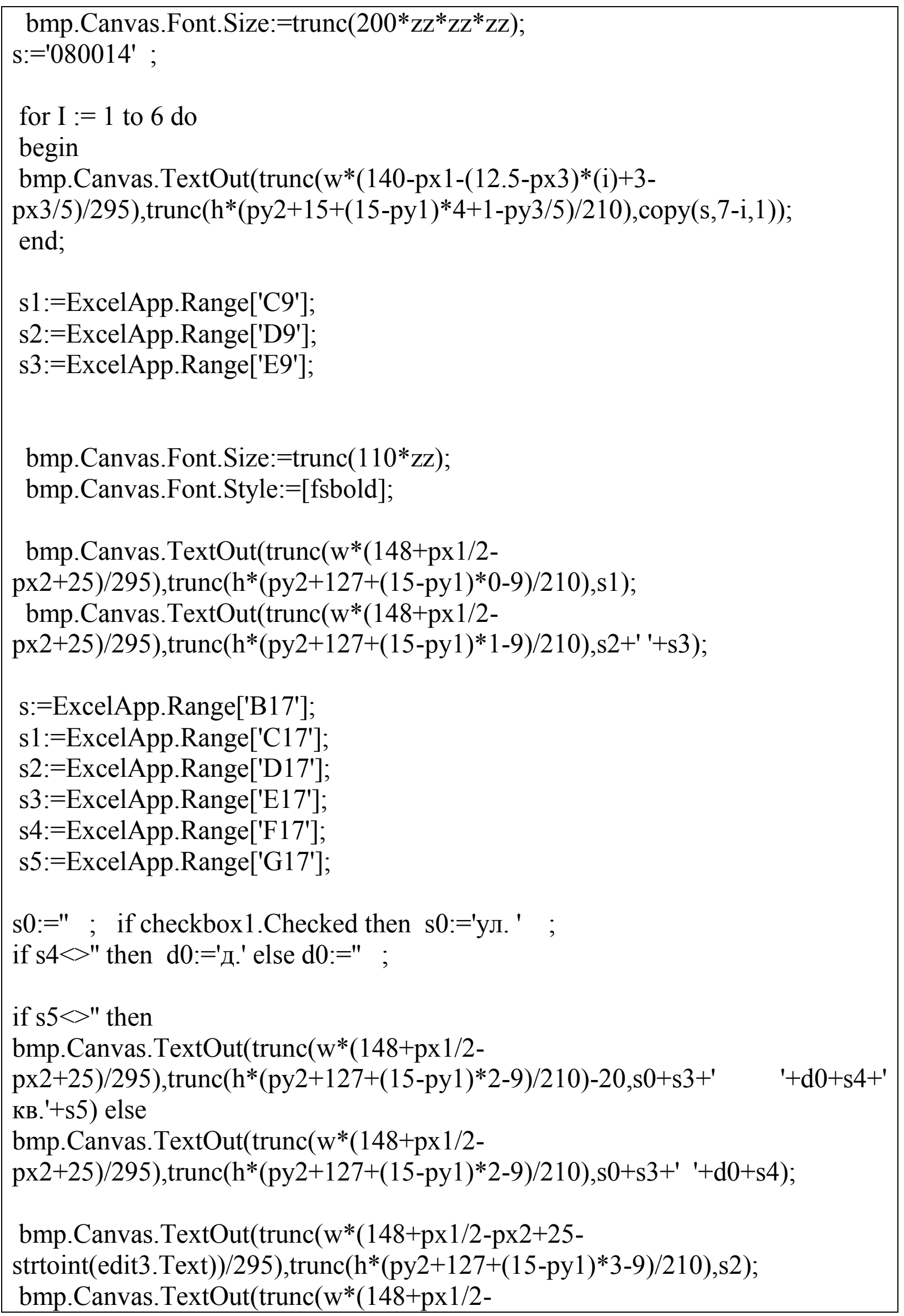




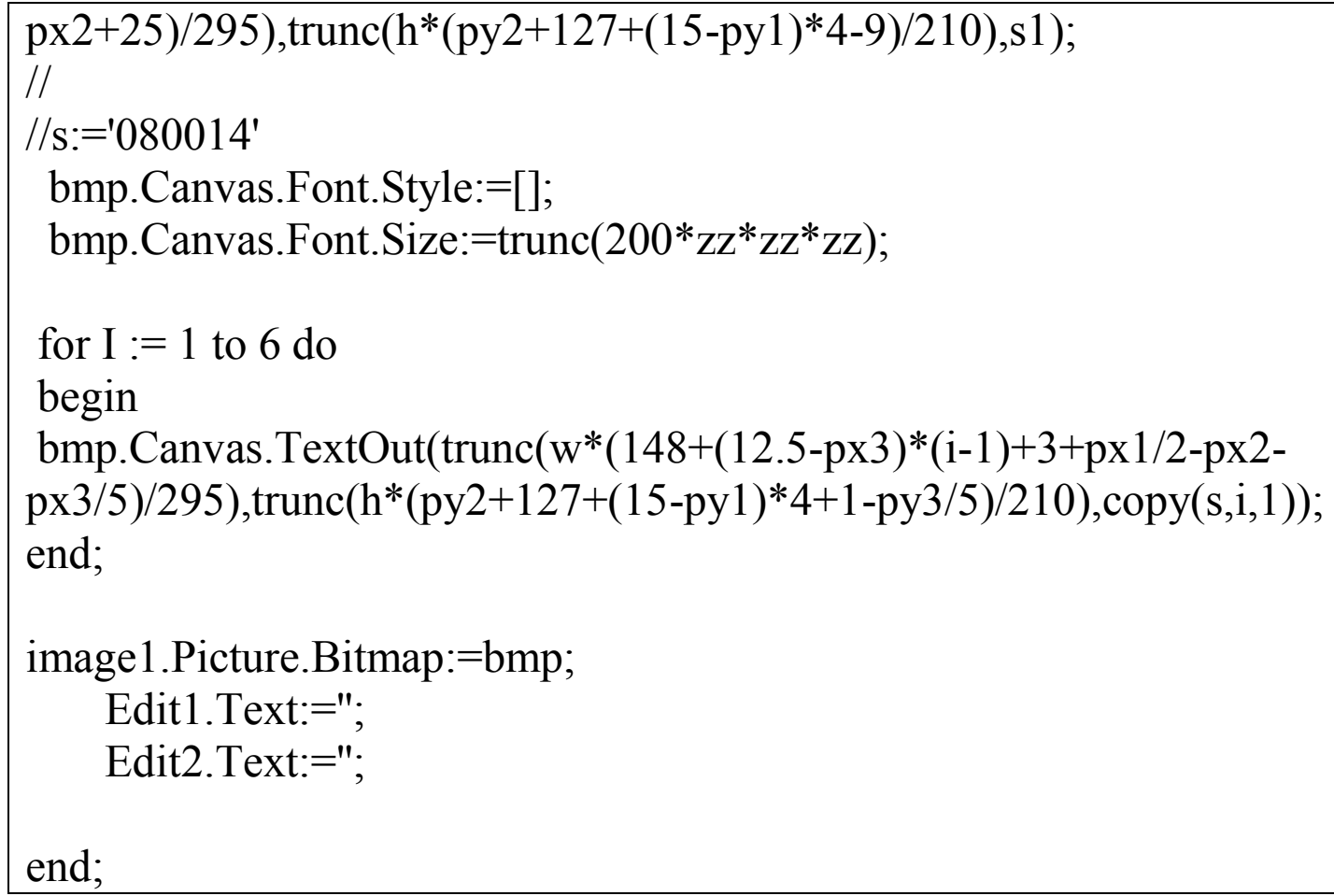

Built-in function print a document converts card in the DIB format and sends it directly to the printer with the size of the card.

code: Delphi

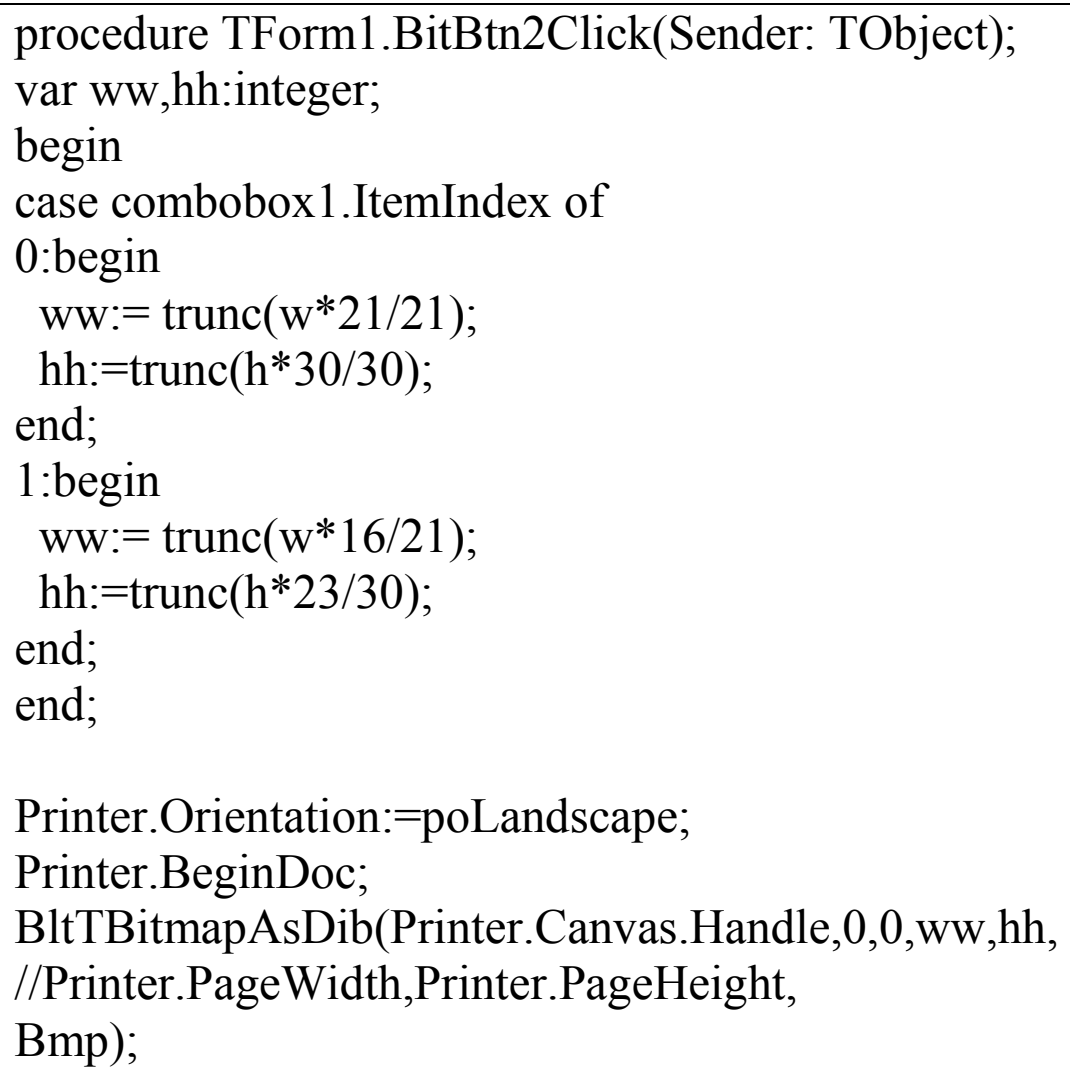


Printer.EndDoc;

end;

The process of conversion is specified algorithm:

code: Delphi

procedure BltTBitmapAsDib(DestDc : hdc; \{Handle of where to blt\}

$\mathrm{x}$ : word; $\quad$ Bit at $\mathrm{x}\}$

$\mathrm{y}$ : word; $\quad\{$ Blt at $\mathrm{y}\}$

Width : word; \{Width to stretch\}

Height : word; $\{$ Height to stretch\}

bm : TBitmap); \{the TBitmap to Blt

var

OriginalWidth :LongInt; $\quad$ \{width of BM

dc : hdc; $\quad$ \{screen dc\}

IsPaletteDevice : bool; $\quad$ if the device uses palettes

IsDestPaletteDevice : bool; $\quad$ if the device uses palettes\}

BitmapInfoSize : integer; $\quad$ \{sizeof the bitmapinfoheader\}

lpBitmapInfo : PBitmapInfo; $\quad$ the bitmap info header

hBm : hBitmap; $\quad$ \{handle to the bitmap

hPal : hPalette;

\{handle to the palette\}

OldPal : hPalette; $\quad$ \{temp palette

hBits : THandle; $\quad$ \{handle to the DIB bits

pBits : pointer; $\quad$ \{pointer to the DIB bits\}

1PPalEntriesArray : PPalEntriesArray; \{palette entry array

NumPalEntries : integer; $\quad$ number of palette entries

$\mathrm{i}$ : integer; $\quad$ \{looping variable\}

begin

$\{$ SIFOPT $\mathrm{R}+$ \}

$\{\$ D E F I N E$ CKRANGE $\}$

$\{\$ R-\}$

$\{\$ E N D I F\}$

OriginalWidth $:=\mathrm{bm}$.Width;dc $:=\operatorname{GetDc}(0)$;IsPaletteDevice $:=$

GetDeviceCaps(dc, RASTERCAPS) and RC_PALETTE $=$ RC_PALETTE; dc $:=$ ReleaseDc $(0, \mathrm{dc})$;

if IsPaletteDevice then BitmapInfoSize $:=$ sizeof(TBitmapInfo) +

(sizeof(TRGBQUAD) * 255) else BitmapInfoSize := sizeof(TBitmapInfo);

GetMem(lpBitmapInfo, BitmapInfoSize);FillChar(lpBitmapInfo^,

BitmapInfoSize, \#0);

lpBitmapInfo ${ }^{\wedge}$.bmiHeader.biSize $:=$

sizeof(TBitmapInfoHeader);lpBitmapInfo ${ }^{\wedge}$.bmiHeader.biWidth :=

OriginalWidth; 


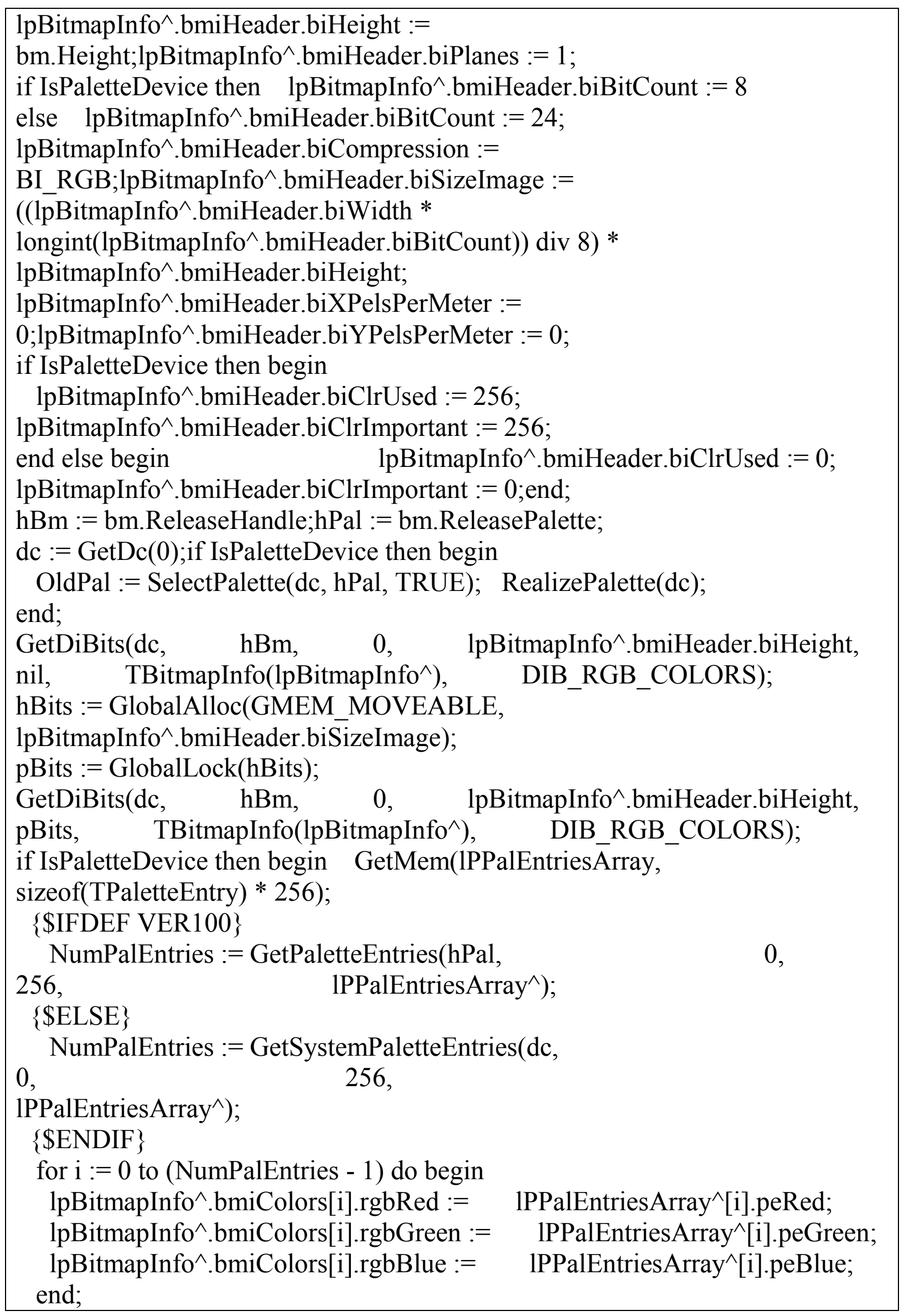




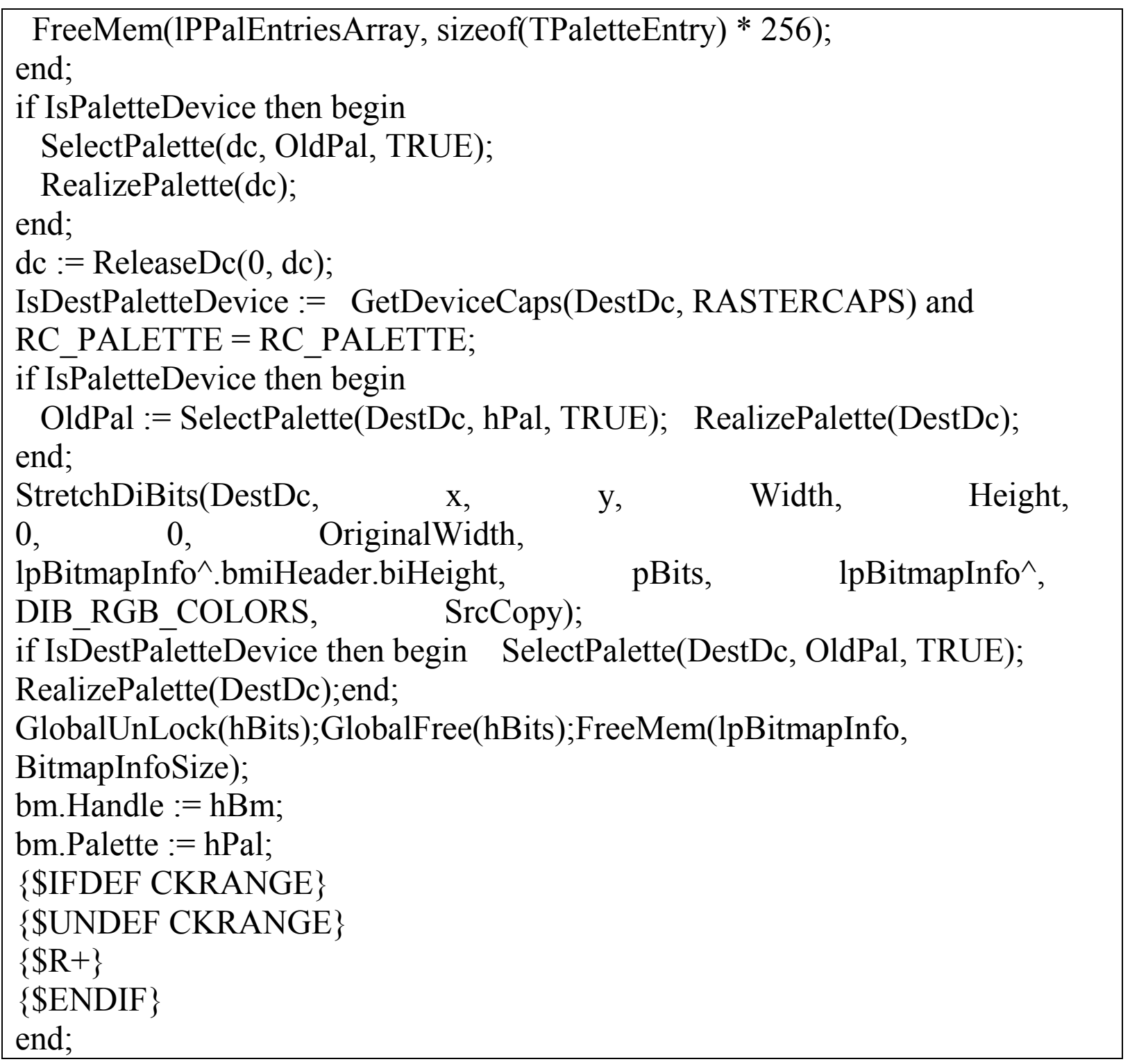




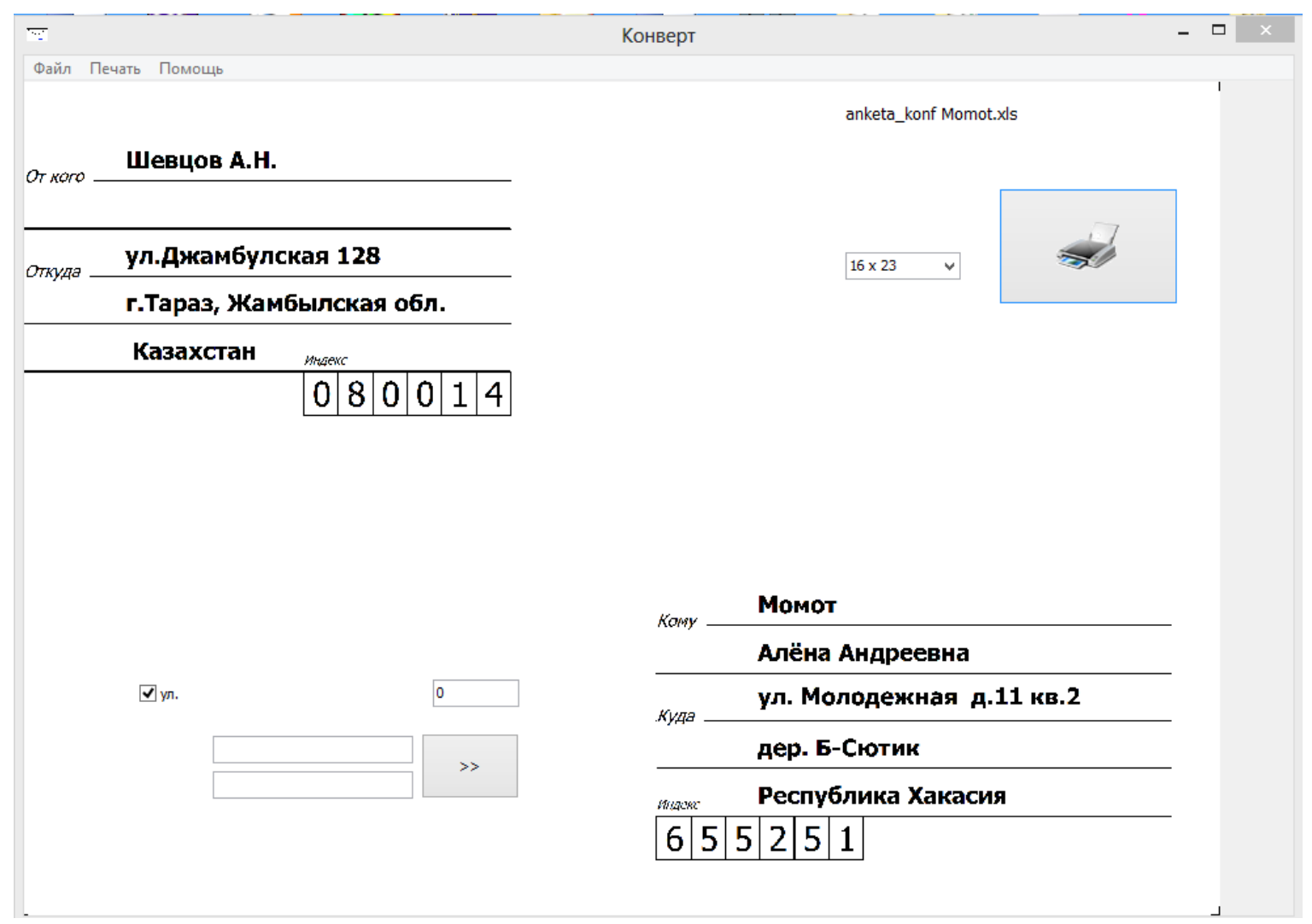

Figure 1 - The Automated system creation blanks.

The obtained system, and algorithms demonstrate an example of creating an automated system to create documents on the basis of initial and current data as well as certain design standards (Fig.1), and databases created in different formats. The system can be implemented in various organizations faced with the necessity of sending letters by mail.

\section{Bibliography}

1. ELMA: Электронный документооборот. [Электронный ресурс]. URL : http://www.elma-bpm.ru/product/e-doc/ (дата обращения: 21.07.2013).

2. Система электронного документооборота. [Электронный ресурс]. URL: http://www.prostoy.ru/145.html (дата обращения: 21.07.2013).

3. Семейство программных продуктов «Канцлер» для созданияСЭД. [Электронный pecypc]. URL : http://www.kancler.by/ (дата обращения: 21.07.2013).

4. Электронный документооборот. [Электронный ресурс]. URL : http://www.docsvision.com/ (дата обращения: 21.07.2013).

5. Система электронного документооборота (СЭД): решаемые задачи. [Электронный pecypc]. URL: http://elektronnij-dokumentooborot.1ckpd.ru/ (дата обращения: 21.07.2013). 
6. Система электронногодокументооборота и автоматизации бизнеспроцессов. [Электронный ресурс]. URL : http://www.evfrat.ru/ (дата обращения: 21.07.2013).

7. Маруняк А. Какую программу выбрать для автоматизации документооборота. Тест-драйв популярных систем. [Электронный ресурс]. URL: http://www.intalev.ru/library/articles/article.php?ID=5211 (дата обращения: 21.07.2013).

8. 1С для автоматизации документооборота и бизнес-процессов. [Электронный ресурc]. URL: http://документооборот.net/ (дата обращения: 21.07.2013).

9. Автоматизация электронного документооборота (СЭД) Автоматизированная система делопроизводства и электронного документооборота. [Электронный ресурс]. URL : http://www.motiw.ru/docflow/ (дата обращения: 21.07.2013).

10. Программа управления электронными документами. [Электронный pecypc]. URL: http://www.documetr.ru/anot.html (дата обращения: 21.07.2013). 